\title{
Research on the Balance of Local Cultural Imprint and Western Centralism in Films in the Background of Intercultural Communication: A Case Analysis of a World Cinema Baraka
}

\author{
Wenjia Tang \\ Faculty of Arts \& Humanities, University College London, London, Unite Kingdom \\ wenjia.tang.18@ucl.ac.uk
}

\begin{abstract}
In the process of cultural globalisation, world cinema has emerged as a new genre of film. It generally attempts to break the limitations of today's film market and expand the horizon of audiences. World cinemas prefer to place the objective expression in the background of a nonEuropean and Hollywood content, show the civilization and sceneries in other regions in the world, especially developing countries. However, due to the influence of the cooperation of global film factories on the production and distribution all over the world, these films not only fail to escape from the limitations of Western centralism but also find it difficult to display local ideology in their expression. This essay will analyse a classic world cinema Baraka to illustrate how world cinemas expressing their local characteristics through a Western filter.
\end{abstract}

Keywords: world cinemas; western centralism; globalization; local culture; Baraka.

\section{Introduction}

With the gradual acceleration of the process of cultural globalisation, the communication across countries, nations, ethnics, and languages have become an important phenomenon that cannot be ignored in the current global market and has gradually become the mainstream method of cultural production. It could be seen that Products which are completely controlled by one country from their production to distribution are no longer competitive in the world market. On the contrary, cooperation between different civilizations and countries has become the norm. This trend is gradually emerging in the film market too: The boundaries of countries have been blurred. The international cooperation in the film industry has become inevitable and mainstream. Although more countries have participated in film production, the western culture in American Hollywood films still dominates the global film market. Meanwhile, the problem is getting clearer: the homogenized film content has gradually made the audience tired, and some popular films such as Hollywood genres built according to the formulas and rules cannot satisfy the critics and audiences even if they can gain a considerable box office. At this time, these fresh, exotic world films emerged suddenly, attracted the attention of audiences.

Related questions have also been mentioned because of the rise of world cinemas: whether these films can truly express the local culture and achieve the ' real ' realism (Robert, 1994). This essay will use Baraka as a case and argue that in the context of industrial globalisation, world cinemas are not the simple display of local cultural symbols, but Western-colored observations and understanding of third-world countries. They have been influenced by the interpretation of Western mainstream culture.

This essay will be divided into two parts. First, it will explain what the world cinema is and whether Baraka can be considered as a world cinema or not. In the second part, this essay will clarify the relationship between film images and social culture and explain why the images displayed by Baraka are not a pure portrayal of local reality but an interpretation by a director influenced by Western culture.

\section{The Definition of World Cinema and the Interpreting of Baraka}

How could a film be thought of as a world cinema? This question seems to be challenging to find an answer which is accurate and accepted by everyone. Gazetas (2008, pp. 120) believes that the world cinema is the one produces in a non-Western environment and use non-English languages. On 
the other hand, Chanan (2011) proposes that the world cinema is a definition related to the film market. According to the different cultural backgrounds and identities of people, there are many possibilities for the definition of world cinema. In many contexts, when people talk about the category of world cinema, they all treat it with the influence of Western Centralism. According to them, films are considered to be Western or others. World cinema is "the other" of Hollywood mainstream films.

There is a need for understanding the film itself while understanding the film production before getting an answer about what is a world cinema. Some questions were raised to help a better answer to this question: Who are the target audiences of this film? Whether this film has achieved an excellent box office and reputation within these audiences? Do audiences from different cultures backgrounds have different perspectives on the same film?

Judging from the above questions, Baraka is in line with the definition of a world cinema. Baraka had been shown in 19 countries over the world. In this film, the vast majority of the images displayed is in non-Western contents and relates to anti-industrialisation and modernisation. These different cultures and identities constitute a preliminary impression of the world outside the West, for example, East Asia, Africa, and other Third World Countries. Those topics are obviously different from modernity and capitalism in Hollywood films.

There is also some data that makes Baraka cannot be fully defined as a world cinema. Firstly, Baraka was produced by American director Ron Fricke and released by a US film company SAMUEL GOLDWYN. It earned \$1,332,110 of the box office in American film markets (Boxofficemojo.com, 2018). Additionally, the modes of human survival and countries' developments presented in Baraka are all similar to each other. They are homogenised to be classified as the mainstream in the Western culture. The dual features make Baraka difficult to be defined as a world cinema or a western cinema.

The difficulty comes from the global cooperation of the film industry. The production and distribution of films are no longer confined to a single country independently. The national identity of the film is diluted. A new production model is born: multinational cooperation and technology sharing help films screen in various countries around the world. More multi-national filmmakers are participating in the process, making the films which have the opportunity to be defined as world cinemas.

The film Baraka strives to show exotic features concerning its expression and themes. The name 'Baraka' derives from an ancient Sufi word. It has a rich meaning and can be understood as "blessing," "breathing," or "the essence of life as it appears in evolution." The director Frick said that the main purpose of this film is to pray for the humanity and the earth (Dick, 2009). To complete this film, Frick planned for five years and spent 14 months in six continents. This film cost a total of 4 million US dollars (Roberts, 1998).

The film shows local sceneries in 24 countries. Different customs, environments, and cultures are linked together in a nonlinear manner. Roberts (1998) believes this film is a record of the human life and can be seen as an anthropological documentary.

The film presents a large number of scenes with oriental religious and philosophical meanings: the snow-capped Himalayas, the red-faced monkeys soaked in hot springs, the temples in Nepal, the melodious morning bells, and the rising sun; monks who pray in the lights of candles; the old Japanese courtyard; religious ceremonies... The film does not follow the narrative order. The screens with similar meanings and topics are edited together to guide the audiences to understand the director's intentions (Rodriguez-Plate, 2017). For example, the director spliced the image of a female worker who made cigarettes in a tobacco factory in Indonesia with the screen that a man who smoked a cigarette while standing in a subway station in Tokyo. The tattooed man in the Japanese bathhouse was also connected to the man in the primitive tribe who was painted on his body. It also compares the steel-cement forest in Hong Kong to the White City Cemetery in Ecuador. All images are linked together to encourage audiences to look for similarities in relevance in the midst. At the same time, it also expresses the commonalities of different cultures in the world. It spans the borders of civilisations, displays the standard living environment and values of humanity, and depicts a picture of "global village". 
In addition to the editing, the film also uses a montage to splice together the close-ups of modern civilisation's plundering of the environment and the faces of people who still maintain in original tribes. It shows the impact of industrialisation on nature, as well as the fear of modern civilisation.

The movie uses editing to create meaning for the images. The natural landscape and faith in the third world countries constitute the opposite of modernity. These alienated cultural symbols are observed by the directors and audiences from Western cultural backgrounds. Through the display of the natural environment and the religious activities of the human society, the film tries to explain how civilisation was born and how it was destroyed in a similar way.

\section{World Cinemas under the Influence of Western Cultural Symbols}

In modern society, films are no longer used merely as a means of entertainment, they also convey cultural and value symbols and participate in all aspects of life. Murray (1985) is the proponent of this view, and he argues that images are the foundation for conquering the world in this era. Rodriguez-Plate (2017) also holds a similar view to him. In his opinion, watching films has become a part of constructing social reality. The audiences' understanding of race, religion, gender, and nationality may come from films or be influenced by films (Chamarette, 2015). In other words, the natural scenery, social activities, and interpersonal relationships in other countries represented by Baraka are an opportunity for the audience who are unfamiliar with these cultures to come into contact with the outside world.

For viewers, even if they understand that films have artistically processed and selectively expressed reality, they still cannot escape from the effects of the information network constructed by cultural symbols. It can be said that films not only affect audiences' acceptation of other cultures but also shape their understanding of the real world (Rodriguez-Plate, 2017)

As a documentary film, Baraka was asked to display the content truly and neutrally. When watching this film, the audience naturally assumed that all the images and expressions they were exposed to were authentic. This is the audience's unconscious recognition of the documentary. Therefore, it is crucial for Baraka to demonstrate the 24 countries it was photographed correctly and comprehensively because the audience's understanding of these screens has a chance to affects their understanding of the reality in those countries. Robert (1994) does not think that these images could be completely objective. He counters that the narrator's own cultural background will change or even distort their expression of things. It suggests the western background of Baraka's director makes these cultures in the East and other parts of the world unable to be directly conveyed to the audience.

Both Tomaselli, Jun, and de la Garza (2016) and Robert (1994) show considerable overlap. Tomaselli, Jun, and de la Garza argue that when a work of art tries to display another culture, the work not only transmits the image but also conveys the understanding of the culture behind the image by the creator. Therefore, when Americans were making Baraka in 24 countries on six continents, what matters is not what they choose to show, but why they accept these cultural symbols and how they deal with these symbols to convey the meaning. In the process of shooting pictures, selecting materials, and editing, cultural communication and understanding have already been implied.

As mentioned above, the director used montage when he was dealing with a large number of meaningless images he had obtained, making these screens no longer a random collage, but a conscious combination for new metaphors. The director's manipulation of material contains his understanding of those materials. At this point, the film is no longer purely observation about the world outside the Western world; it has already been re-interpreted and given a new meaning.

It is believed by Murray (1985) that the world cinema made by white people still cannot escape from the embarrassment of white-centred. They do not show enough respects to the culture and production status of other races. In Baraka, many images depicting the social group life and the city are taken from a high angle; the lens does not enter the group of people, but a distance from these groups with the observation of alienation. These screens are observations above and beyond these societies and people, with the divine view of the heavens overlooking the suffering of sentient beings. Not only the film itself, but the social reality also cannot be separated entirely from the mainstream 
culture of the United States and the Western world. This makes it easier for Western filmmakers to simplify other cultures into a group of local cultural symbols (Murray, 1985).

The film drowns all traditions, all geographical positions, and all cultures in the same medium. These Eastern or African societies have been condensed into a symbol of civilisation. Filmmakers do not care about the diversity of each culture. They only need to select representative images and symbols. It seems that this is enough to show the excitement of the external world. Robert (1994) shares the same view as Murray does. He believes that this symbolic expression is essentially the Western compassionate sympathy for "secondary" culture. Jelača (2017) indicates that this act of cultural spread implies the legacy of colonialism.

There is varied opinion as Roberts (1998) mentions that Baraka is trying to downplay the influence of Western civilisation on these world images. An illustration can be seen here is that the film did not use the English language. Language is seen as a symbol of the output of cultural symbols in films. Baraka does not use dialogues and narrations; it covers the natural sound effects and distinctive music from different countries and regions instead. This reduces the discomfort of language intrusion and increases the diversity of other cultures in the world.

\section{Conclusion}

The topic of world cinemas and their relationship with cross-cultural communication are still being debated. It is difficult to accurately understand Baraka under the framework of the world cinema. There is a need for further understanding of the relationship between Western culture and the civilisation that the film presents. It can be seen that the film is trying to demonstrate a wider range of customs and social realities, and discusses philosophical propositions about the survival and destruction of human beings in the context of the world. Due to these attempts, the director of this film gave these scenes a meaning outside of the screen and was integrated with his American cultural background. He was consciously and selectively presented the images to the audiences. Therefore, Baraka also failed to totally jump out of the framework of Western mainstream culture when it displayed a very exotic world scene.

\section{References}

[1]. Chamarette, J. Embodied Worlds and Situated Bodies: Feminism, Phenomenology, Film Theory. Signs: Journal of Women in Culture and Society, vol.40 (2015), pp.289-295.

[2]. Gazetas, A. An introduction to world cinema. 2nd ed. Jefferson: McFarland, (2008) pp.120.

[3]. Murray, T. Screening the Camera's Eye: Black and White Confrontations of Technological Representation. Modern Drama, vol.28 (1985), pp.110-124.

[4]. Roberts, M.. "Baraka": World Cinema and the Global Culture Industry. Cinema Journal, (1998) pp.62-82.

[5]. Tomaselli, K., Jun, Z. and de la Garza, A. Culture, communication and cross-media arts studies: transnational cinema scholarship perspectives. Transnational Cinemas, vol.8 (2016), pp.160-163. 